\title{
STUDIES ON MALAYAN FILARIASIS IN CHE-JU ISLAND, KOREA
}

\section{Vector Mosquitoes of Malayan Filariasis}

\author{
Yoshito Wada ${ }^{1}$, Daisuke Katamine ${ }^{2}$ and Moon You $\mathrm{OH}^{3}$ \\ Received for publication 31 October 1973
}

\begin{abstract}
Although 14 species of mosquitoes were collected in Che-ju Island, Korea in August and September, 1970-1972, dominant mosquitoes feeding on man around dwelling houses were Culex pipiens pallens and Aedes togoi. Natural infections with infective larvae of Brugia malayi were demonstrated only in Ae. togoi. It is considered from these facts that the main vector of malayan filariasis in Che-ju Island is Ae. togoi. Anopheles sinensis which is known as the vector of malayan filariasis in other areas does not seem to act an important role in the transmission in Che-ju Island, because the desnity is very low owing to the scarcity of suitable breeding places. The period for the larvae of Brugia malayi to mature in Ae. togoi was estimated to be between 6 and 9 days from the results obtained by dissecting the females of the mosquito reared in the laboratory for various days after the collection at houses with microfilarial carriers. This period is much shorter than in the case of Wuchereria bancrofti. The breeding of Ae. togoi was observed mainly in rock pools on the seacoast, and only very rarely in artificial water containers within villages. Generally, adult females of this mosquito were abundantly found at houses near to the seacoast, and the density decreased with the distance from the seacoast. Similar tendency was seen in the distribution of the patients of malayan filariasis.
\end{abstract}

Che-ju Island, Korea, which is $1,820 \mathrm{~km}^{2}$ in area, is situated about $370 \mathrm{~km}$ south-west-west to Tsushima Islands, Japan. In the center of the Island there is a mountain with an altitude of $1,950 \mathrm{~m}$ and the plain area is rather small so that rice fields are not much developed. Human filariasis caused by Brugia malayi is known to distribute densely in the Island, in which mosquitoes were studied in 1970, 1971 and 1972 in relation to malayan filariasis. The results obtained will be reported in this paper, as the second part of studies on malayan filariasis in Che-ju Island, Korea.

\section{Mosquitoes Found in Che-Ju Island}

Larvae (including pupae) and adults of mosquitoes were collected in August and September, 1970, 1971 and 1972, at nine locations on Che-ju Island, as shown in

1 Department of Medical Zoology, Nagasaki University School of Medicine, Nagasaki, Japan.

2 Department of Parasitology, Institute for Tropical Medicine, Nagasaki University, Nagasaki, Japan.

3 Department of Veterinary Medicine, Faculty of Agriculture, Che-ju National University, Che-ju Do, Korea. 
Fig. 1. Collections of larvae were made by a dipper and a pipette at their breeding places, and adults by an aspirator and a small hand net and also by a light trap.

Mosquito species found in Che-ju Island by collections of larvae and adults are given in Table 1. Mosquitoes collected as the larval stage belonged to 14 species, in which 8 were obtained as the adult stage also. In the below, some biological notes on the 14 species are given.

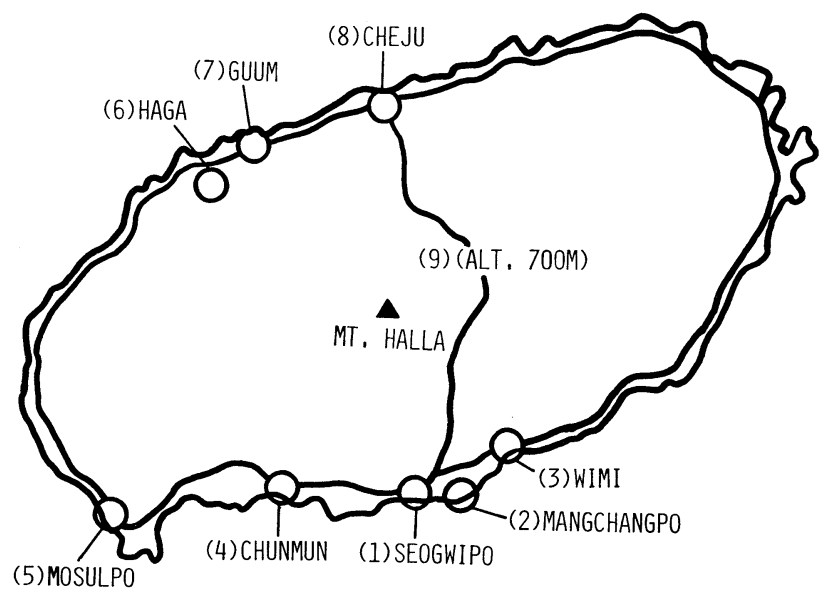

Fig. 1 A map of Che-ju Do, showing the sites of mosquito collections.

TABle 1 Mosquito species found in Che-ju Island, August 21-September 18, 1970 and August 14-September 4, 1971

\begin{tabular}{|c|c|c|c|c|c|c|c|c|c|c|}
\hline Species & Stage & & & & & calit & & & & \\
\hline Anopheles sineroides & $\mathrm{L}$ & & & & & & & & & (9) \\
\hline Anopheles sinensis & A, L & (1) & & (3) & & & (6) & (7) & & \\
\hline Armigeres subalbatus & A, L & (1) & & (3) & & & & & & \\
\hline Aedes albopictus & A, L & (1) & & (3) & (4) & & & (7) & & \\
\hline Aedes nipponicus & $\mathrm{L}$ & & & (3) & & & & & & \\
\hline Aedes hatorii & $\mathrm{L}$ & & & & (4) & & & & & (9) \\
\hline Aedes japonicus & $\mathrm{L}$ & & & & & & & & & (9) \\
\hline Aedes togoi & A, L & (1) & (2) & (3) & & (5) & & (7) & & \\
\hline Aedes vexans nipponii & $\mathrm{A}, \mathrm{L}$ & (1) & & (3) & & & & & & (9) \\
\hline Culex hayashii & $\mathrm{L}$ & & & & & & & & & (9) \\
\hline Culex bitaenioryhnchus & A, L & (1) & & (3) & & & & & & \\
\hline Culex mimeticus & $\mathrm{L}$ & & & & & & & & & (9) \\
\hline Culex tritaenioryhnchus & A, L & (1) & & (3) & & & (6) & & (8) & \\
\hline Culex pipiens pallens & A, L & (1) & (2) & (3) & & (5) & (6) & & (8) & \\
\hline
\end{tabular}

A: adults; L: larvae

(1) Seogwipo, (2) Mangchangpo, (3) Wimi, (4) Chunmun, (5) Mosulpo,

(6) Haga, (7) Guum, (8) Cheju, (9) Halfway (Alt. 700 m) up Mt. Halla 
Anopheles (Anopheles) sinensis Wiedemann, 1828: Larvae were found in rice fields, ponds, and rock pools on the river bed. Adults were collected by light traps. In Japan this mosquito is a commonest species in rural areas, but rather few in number in the Island because breeding places are found only to a small extent.

Anopheles (Anopheles) sineroides Yamada, 1924: Larvae were collected from a shallow abondoned well and a small pond, situated at an altitude of ca. $700 \mathrm{~m}$, halfway up Mt. Halla. This species seems to like cooler water for breeding than Anopheles sinensis.

Aedes (Finlaya) japonicus (Theobald, 1901): Larvae were common in rock pools on the river bed situated halfway up Mt. Halla. We were never bitten by adults of this mosquito while collecting the larvae at the daytime.

Aedes (Finlaya) togoi (Theobald, 1907): This is a commonest species in Che-ju Island. Larvae were very abundant in rock pools on the seacoast, and rare in artificial water containers in the inland area. Adults were collected in a large number in dwelling houses, particularly near to the seacoast, and also by light traps. Feeding on villagers is very active in the nighttime.

Aedes (Finlaya) hatorii Yamada, 1921: Larvae were found in rock pools on the river bed, but the number seems considerably smaller than Aedes japonicus.

Aedes (Finlaya) nipponicus LaCasse et Yamaguti, 1948: A larva was collected from a hole of the camellia tree at Wimi, accompanied larvae having been Aedes albopictus. This species seems rare in the Island.

Aedes (Stegomyia) albopictus (Skuse, 1895): This is a common species. Larvae were found in artificial containers around dwelling houses and in tree holes. Adults are a daytime feeder on man.

Aedes (Aedimorphus) vexans nipponii (Theobald, 1907): Larvae were collected in rock pools on the river bed around villages and in a ground pool halfway up Mt. Halla, and adults by light traps. The number was not very large in the Island. Adults are apparently exophilous in behavior, and scarcely found in dwelling houses.

Armigeres (Armigeres) subalbatus (Coquillett, 1898): Larvae were found in artificial containers with dirty water, and adults were encountered sometimes in dwelling houses.

Culex (Neoculex) hayashii Yamada, 1917: This species is known to be an amphibian feeder. Larvae were collected in small ponds within a forest half way up Mt. Halla.

Culex (Culex) bitaeniorhynchus Giles, 1901: Larvae were found in rock pools and ground pools on the river bed. This species was not numerous in the Island.

Culex (Culex) tritaeniorhynchus summorosus Dyar, 1920: Larvae were collected from rice fields, road-side ditches, and rock pools and ground pools on the river bed, and adults by light traps. This species was rather small in number.

Culex (Culex) mimeticus Noé, 1899: Larvae were collected in a small pond halfway up Mt. Halla.

Culex (Culex) pipiens pallens Coquillett, 1898: This species is a commonest mosquito around dwelling houses in the Island. Larvae breed in artificial containers, road-side ditches, rock and ground pools on the river bed, and so on. Adults are abundant in dwelling houses, and attracted to light traps. This feeds preferably 
on man.

Besides the above-mentioned species, Chun (1968) reported Anopheles (Anopheles) lesteri Baisas et Hu, Culex (Lutzia) vorax (Edwards) and Culex (Culex) vagans Wiedemann. These species seem to be small in number.

Dominant species of mosquitoes feeding on man can be seen more clearly by the numbers of female mosquitoes collected at dwelling houses or by using light traps set around dwelling houses, as seen in Table 2. The most dominant mosquito was $C$. p. pallens, and the next Ae. togoi, at dwelling houses in 1970, though the number of $A e$. togoi seemed small at Haga which was situated some distance from the seacoast. The data by light traps show similar results excepting An. sinensis. The distribution of An. sinensis is influenced largely by the situation of rice fields, and 20 specimens of An. sinensis out of 272 in total by light traps at Seogwipo is probably explained by the fact that the site of light trap collection was very near to rice fields. However, the population of this mosquito in the island is considered to be rather small, owing to the small area of rice fields.

TABLE 2 Numbers of female mosquitoes collected in Che-ju Island, August 21-September 15,1970

\begin{tabular}{|c|c|c|c|c|c|c|c|c|c|c|c|}
\hline \multirow{2}{*}{$\frac{\text { Collection method }}{\text { Locality* }}$} & \multicolumn{6}{|c|}{ At dwelling houses } & \multicolumn{4}{|c|}{ By light traps } & \multirow{2}{*}{ Total (\%) } \\
\hline & $(1)$ & (3) & (5) & (6) & Total & $(\%)$ & $(1)$ & (3) & Total & $(\%)$ & \\
\hline Number of collections & 9 & 327 & 1 & 11 & \multicolumn{2}{|c|}{348} & 7 & 1 & \multicolumn{2}{|l|}{8} & 356 \\
\hline An. sinensis & & & & & & & 20 & & 20 & $(7.1)$ & (1.5) \\
\hline Ar. subalbatus & 4 & & & & 4 & $(0.4)$ & & & & & $(0.3)$ \\
\hline Ae. albopictus & 3 & 4 & & & 7 & $(0.6)$ & 2 & & 2 & $(0.7)$ & $(0.7)$ \\
\hline Ae. togoi & 3 & 308 & 10 & & 321 & $(29.8)$ & 10 & 1 & 11 & $(3.9)$ & 332 (24.4) \\
\hline Ae. vexans nipponii & & & & & & & 2 & & 2 & $(0.7)$ & $(0.1)$ \\
\hline C. tritaeniorhynchus & & & & & & & & 1 & 1 & $(0.4)$ & $(0.1)$ \\
\hline C. p. pallens & 159 & 504 & 64 & 19 & 746 & $(69.2)$ & 238 & 8 & 246 & $(87.2)$ & $992 \quad(72.9)$ \\
\hline Total & 169 & 816 & 74 & 19 & 1,078 & $(100.0)$ & 272 & 10 & 282( & 100.0) & $1,360(100.0)$ \\
\hline
\end{tabular}

* (1) Seogwipo, (3) Wimi, (5) Mosulpo, (6) Haga

\section{Natural Infections of Mosquitoes}

All female mosquitoes collected at dwelling houses were, otherwise stated, preserved in $80 \%$ ethanol, on the day of, or from 4 to 10 days after collection, for later examination of filarial larvae. In 1970, mosquitoes were collected at all of 327 houses in Wimi-1-Ri, the western part of Wimi (see Table 2), therefore the natural infections of mosquitoes reflect the situation in the transmission of filariasis within the area concerned. On the other hand, in 1971 attempts were made to collect mosquitoes at dwelling houses only with microfilarial positives particularly in Mangchangpo, but natural infections can be compared between mosquito species, since all mosquitoes found were collected at each house.

The results of natural infections with each stage larvae of Brugia malayi in mos- 
quitoes are given in Table 3. Possibility of other filariae than B. malayi can not completely be excluded, however it may be justified to say that all filariae found in the mosquitoes are $B$. malayi from the reasons that all the 33 infective stage (third stage) larvae showed the characteristics of malayan filariae, younger stage larvae with terminal nuclei were found only in the thorax muscle, and only malayan filariasis is reported from humans in Che-ju Island.

TABLE 3 Natural infections with each stage larvae of Brugia malayi in mosquitoes collected at dwelling houses, Che-ju Island, 1970 and 1971

\begin{tabular}{|c|c|c|c|c|c|c|c|}
\hline \multirow[b]{2}{*}{$\begin{array}{c}\text { Mosquito } \\
\text { species }\end{array}$} & \multirow[b]{2}{*}{ Year } & \multirow{2}{*}{$\begin{array}{c}\text { Days } \\
\text { after } \\
\text { collection } \\
\end{array}$} & \multirow{2}{*}{$\begin{array}{l}\text { No. of } \\
\text { mosquitoes } \\
\text { dissected }\end{array}$} & \multirow{2}{*}{$\begin{array}{c}\text { Total } \\
\text { No. }(\%) \\
\text { infected }\end{array}$} & \multicolumn{3}{|c|}{ No. $(\%)$ of mosquitoes infected with } \\
\hline & & & & & $\begin{array}{l}\text { 1st stage } \\
\text { larvae }\end{array}$ & $\begin{array}{l}\text { 2nd stage } \\
\text { larvae }\end{array}$ & $\begin{array}{c}\text { 3rd stage } \\
\text { larvae }\end{array}$ \\
\hline Ae. togoi & 1970 & $0 *$ & 308 & $\begin{array}{c}27 \\
(8.8)\end{array}$ & $\begin{array}{c}19 \\
(6.2)\end{array}$ & $\begin{array}{c}4 \\
(1.2)\end{array}$ & $\begin{array}{c}5 \\
(1.6)\end{array}$ \\
\hline C.p.pallens & 1970 & $0 *$ & 504 & $\begin{array}{c}2 \\
(0.4)\end{array}$ & $\begin{array}{c}2 \\
(0.4)\end{array}$ & 0 & 0 \\
\hline Ae. albopictus & 1970 & $0 *$ & 4 & $\begin{array}{c}0 \\
(0.0)\end{array}$ & 0 & 0 & 0 \\
\hline Ae. togoi & 1971 & $0^{*}$ & 292 & $\begin{array}{c}12 \\
(4.1)\end{array}$ & $\begin{array}{c}3 \\
(1.0)\end{array}$ & $\begin{array}{c}3 \\
(1.0)\end{array}$ & $\begin{array}{c}6 \\
(2.1)\end{array}$ \\
\hline C.p. pallens & 1971 & $0 *$ & 329 & $\begin{array}{c}1 \\
(0.3)\end{array}$ & $\begin{array}{c}1 \\
(0.3)\end{array}$ & 0 & 0 \\
\hline Ae.albopictus & 1971 & $0 *$ & 2 & $\begin{array}{c}0 \\
(0.0)\end{array}$ & 0 & 0 & 0 \\
\hline Ae. togoi & 1971 & $4-10$ & 264 & $\begin{array}{c}27 \\
(10.2)\end{array}$ & 0 & $\begin{array}{c}9 \\
(3.4)\end{array}$ & $\begin{array}{c}22 \\
(8.3)\end{array}$ \\
\hline C.p.pallens & 1971 & $4-10$ & 235 & $\begin{array}{c}1 \\
(0.4)\end{array}$ & 0 & $\begin{array}{c}1 \\
(0.4)\end{array}$ & 0 \\
\hline
\end{tabular}

* Resting mosquitoes were collected in the daytime and fixed in $80 \%$ ethanol in the evening on the same day, so that it is thought that the fed females among them passed about one day or more after blood meal, since both Ae. togoi and C. p. pallens are the night-time feeder.

TABLE 4 Number of Brugia malayi larvae in naturally infected mosquitoes shown in Table 3

\begin{tabular}{|c|c|c|c|c|c|c|}
\hline \multirow{2}{*}{$\begin{array}{l}\text { Mosquito } \\
\text { species }\end{array}$} & \multirow[b]{2}{*}{ Year } & \multirow{2}{*}{$\begin{array}{c}\text { Days } \\
\text { after } \\
\text { collection }\end{array}$} & \multirow{2}{*}{$\begin{array}{l}\text { No. of } \\
\text { infected } \\
\text { mosquitoes }\end{array}$} & \multicolumn{3}{|c|}{$\begin{array}{l}\text { Mean (maximum) No. of malayi } \\
\text { larvae/mosquito }\end{array}$} \\
\hline & & & & 1st stage & 2nd stage & 3rd stage \\
\hline Ae. togoi & 1970 & $0 *$ & 27 & $3.5(12)$ & $3.8(8)$ & $2.0(3)$ \\
\hline C.p.pallens & 1970 & $0 *$ & 2 & $1.5(2)$ & & \\
\hline Ae. togoi & 1971 & $0 *$ & 12 & $2.0(4)$ & $1.7(3)$ & $2.7(5)$ \\
\hline C.p. pallens & 1971 & $0 *$ & 1 & $1.0(1)$ & & \\
\hline Ae. togoi & 1971 & $4-10$ & 27 & & $3.2(10)$ & $9.2(47)$ \\
\hline C.p. pallens & 1971 & $4-10$ & 1 & & $1.0(1)$ & \\
\hline
\end{tabular}

* See Table 3 
It is apparent from Table 3 that the infection rate was highest in Ae. togoi among three mosquito species examined. In 1970, 308 females of Ae. togoi were dissected and $27(8.8 \%)$ were found infected, but among 504 C. p. pallens dissected only 2 $(0.4 \%)$ were infected, and no infected Ae. albopictus were found though the number dissected was very small. It was also indicated that only in Ae. togoi the third stage larvae of B. malayi were demonstrated. Similar results were obtained also in 1971, showing the highest infection rate in Ae. togoi over the other two species. The low susceptibility of C.p. pallens is in agreement with Feng (1934) and Hu (1940a and 1948).

The numbers of $B$. malayi larvae in naturally infected mosquitoes are given in Table 4. Ae. togoi had many malayi larvae in their body; in the females examined on the day of the collection the mean numbers for the first, second and third stage larvae were respectively 3.5, 3.8 and 2.0 in 1970 and 2.0, 1.7 and 2.7 in 1971, and from 4 to 10 days after the collection in 1971 the mean numbers for the second and third stage larvae were 3.2 and 9.2. In an extreme case, one female was found to have 47 larvae in the third stage. On the other hand, the mean numbers of malayi larvae in C. p. pallens was much smaller than those in Ae. togoi. Among the four infected females, three had only one larva each and the remaining one had two.

It was a question why the infection rate of $C$. p . pallens was much lower than $A$ e. togoi, considering that the both species were concurrently collected in the same houses and the chances of picking up microfilariae would have been same. Dissected mosquitoes shown in Table 3 were those collected at dwelling houses in the daytime and fixed in $80 \%$ ethanol in the evening on the same day or after keeping for 4-11 days in the laboratory. For this reason, it is thought that infected Ae. togoi and C. p. pallens had passed about one day or more from the infective blood-meal to the dissection, viewing that the both species are the night-time feeder. Besides the mosquitoes mentioned above, fresh-fed mosquitoes were dissected immediately after the collection in the night at microfilarial positive houses, and it was found that infected females of $C$. p. pallens had as many microfilariae in their stomach as $A e$. togoi did.

From these findings, it is assumed that in Ae. togoi the microfilariae which had entered once into the stomach of the mosquito on blood feeding develop very well to the infective stage in the thorax muscle, while in the case of C. p. pallens the microfilariae can be picked up by the mosquito, probably as efficiently as Ae. togoi, but most of them are discharged in droppings and only a few reach to the thorax from the stomach, and furthermore the mortality rate during the development to maturity is very high.

\section{Vector Species in Che-Ju Island}

There have been known several species of mosquitoes which are susceptible to the larvae of $B$. malayi. However, it can be concluded that the main vector of malayan filariasis in Che-ju Island is Ae. togoi, from the facts that large numbers of females were found biting man in dwelling houses and the infection rate with the infective stage larvae was high. The suitability of Ae. togoi as a vector of B. malayi 
has been reported also by Chun (1968), Gun (1960), Kim and Seo (1968), Lee (1969), and Sasa et al. (1951).

Although Anopheles sinensis is a good vector of the parasite (Feng, 1934 and 1936; Ho et al., 1962; Hu, 1940b), the number is small in Che-ju Island. C. p. pallens is a commonest mosquito in the Island, but has an extremely low susceptibility, if any, as mentioned in the earlier section and reported by $\mathrm{Hu}$ (1940a and 1948).

\section{Period for Brugia malayi Larvae to Mature in Mosquitoes}

In Table 5 are given the numbers of $B$. malayi larvae by stage in the infected Ae. togoi females kept at room temperatures (27.4C on the average) for 4-10 days after the collection in 1971. For example, mosquito No. 13 was killed 6 days after the collection and was found to have one second stage larva in the thorax and one third stage larva each in the thorax and in the abdomen. It is rather difficult from Table 5 to give the exact period necessary for $B$. malayi larvae to mature in the mosquito, because it could not be precisely determined when each mosquito took the infective blood-meal. However, such data as Table 5 do give some informations on the developmental period. The females infected only with the second stage larvae

TABle 5 Development of Brugia malayi larvae in Aedes togoi kept in the laboratory after the collection at microfilaria-positive houses, Che-ju Island, 1971

\begin{tabular}{|c|c|c|c|c|c|c|c|}
\hline \multirow{2}{*}{$\begin{array}{c}\text { Days } \\
\text { after } \\
\text { collection }\end{array}$} & \multirow{2}{*}{$\begin{array}{c}\text { Mosquito } \\
\text { No. }\end{array}$} & \multirow{2}{*}{$\begin{array}{l}\text { No. of } 2 \text { nd } \\
\text { stage larvae } \\
\text { Thorax }\end{array}$} & \multicolumn{4}{|c|}{ No. of 3rd stage larvae } & \multirow[b]{2}{*}{ Total } \\
\hline & & & Thorax & Abdomen & Head & Proboscis & \\
\hline 4 & 1 & 1 & & & & & \\
\hline 5 & $\begin{array}{r}2 \\
3 \\
4 \\
5 \\
6 \\
7 \\
8 \\
9 \\
10 \\
11\end{array}$ & $\begin{array}{r}1 \\
2 \\
10 \\
2\end{array}$ & $\begin{array}{l}2 \\
2 \\
3 \\
6\end{array}$ & $\begin{array}{r}14 \\
\\
1 \\
1 \\
4 \\
22\end{array}$ & $\begin{array}{l}7 \\
1 \\
1 \\
3 \\
2\end{array}$ & 19 & $\begin{array}{r}47 \\
1 \\
1 \\
3 \\
6 \\
13 \\
30\end{array}$ \\
\hline 6 & $\begin{array}{l}12 \\
13 \\
14 \\
15 \\
16 \\
17 \\
18 \\
19\end{array}$ & $\begin{array}{l}1 \\
1\end{array}$ & $\begin{array}{l}1 \\
1 \\
2 \\
1 \\
3 \\
5\end{array}$ & $\begin{array}{l}1 \\
1 \\
4\end{array}$ & $\begin{array}{l}2 \\
1 \\
3 \\
1 \\
5\end{array}$ & $\begin{array}{l}14 \\
10\end{array}$ & $\begin{array}{r}2 \\
1 \\
2 \\
3 \\
5 \\
19 \\
24\end{array}$ \\
\hline 7 & 20 & 9 & 1 & & & & 1 \\
\hline 8 & $\begin{array}{l}21 \\
22\end{array}$ & 2 & & & $\begin{array}{l}1 \\
1\end{array}$ & & $\begin{array}{l}1 \\
1\end{array}$ \\
\hline 9 & 23 & & 1 & & & & 1 \\
\hline 10 & $\begin{array}{l}24 \\
25 \\
26 \\
27\end{array}$ & & $\begin{array}{l}1 \\
2 \\
1 \\
3\end{array}$ & $\begin{array}{r}1 \\
17 \\
3\end{array}$ & 2 & 12 & $\begin{array}{r}1 \\
3 \\
18 \\
20\end{array}$ \\
\hline
\end{tabular}


were obtained from 4 to 6 days after the collection, those both with the second and third stage from 5 to 8 days after, and those only with the third stage from 5 to 10 days. Thus, it seems that the developmental period for malayi larvae to mature in $A e$. togoi is between 6 to 9 days, if the fact that the time between the possible infective feed and the fixation in $80 \%$ ethanol is about one day or more (see Remark of Table 3 ) is kept in mind. This is much shorter than 12 and 15 days of the periods at $27^{\circ} \mathrm{C}$ and $25^{\circ} \mathrm{C}$ respectively for $W$. bancrofti larvae in its suitable intermediate host, C. $p$. pallens (Omori, 1957). This short period for the development of B. malayi is supported by reported papers, as seen in Table 6 . Eight species of mosquitoes belonging to Anopheles, Mansonia and Aedes were examined, but all cases suggested the much shorter developmental period for $B$. malayi than that for $W$. bancrofti.

The difference in developmental period between the larvae of $B$. malayi and $W$. bancrofti in their suitable vector mosquitoes would suggest that $A$ e. togoi transmit $B$. malayi much more efficiently than $C$.p. pallens transmit $W$. bancrofti, if other situations are not different. This, in turn, implies that a higher density of vector mosquitoes would be necessary to keep a certain level of microfilarial prevalence of persons in the case of $W$. bancrofti than in B. malayi.

TABle 6 Days for Brugia malayi larvae to become infective in mosquitoes, cited from various sources

\begin{tabular}{|c|c|c|c|}
\hline Mosquito species & Days & Temperature & Reference \\
\hline Anopheles barbirostris & $6.5-$ & & Brug, 1937 (Edeson, 1961) \\
\hline \multirow[t]{4}{*}{ Anopheles sinensis } & $6-12$ & & Brug, 1922 (Belding, 1965) \\
\hline & $6-$ & $29-32^{\circ} \mathrm{C}$ & Feng, 1934 \\
\hline & $6-6.5$ & $29-32^{\circ} \mathrm{C}$ & Feng, 1936 \\
\hline & $6-7$ & $27.1-28.9^{\circ} \mathrm{C}$ & $\mathrm{Hu}, 1940$ \\
\hline Mansonia annulatus & $8.5-$ & & Poynton \& Hodgkin, 1938 \\
\hline Mansonia annulifera & $9.5-$ & & Poynton \& Hodgkin, 1938 \\
\hline \multirow[t]{2}{*}{ Mansonia longipalpis } & $9.5-$ & & Poynton \& Hodgkin, 1938 \\
\hline & -10 & & Wharton, 1957 (Belding, 1965) \\
\hline \multirow[t]{2}{*}{ Mansonia uniformis } & $8-$ & $29-32^{\circ} \mathrm{C}$ & Feng, 1934 \\
\hline & $8.5-$ & & Poynton \& Hodgkin, 1938 \\
\hline Aedes aegypti & $9-$ & & Beckett \& Boothroyd, 1969 \\
\hline \multirow[t]{2}{*}{ Aeges togoi } & $8-9$ & $24-30^{\circ} \mathrm{C}$ & Kim \& Seo, 1968 \\
\hline & $6-10 *$ & & Ramachandran et al., 1961 \\
\hline
\end{tabular}

* Subperiodic Brugia malayi

\section{Biting Periodicity of Ae. togoi}

To know the biting periodicity of $A$ e. togoi is important in relation to the microfilarial periodicity of $B$. malayi. Therefore hourly catches of mosquitoes were made during a night at a hut facing the seacoast of Mangchangpo. All the mosquitoes collected were Ae. togoi. The result is given in Table 7 .

It is seen from Table 7 that the peak activity was around 2:00-4:00. However, it is usual for the pattern of hourly catches of mosquitoes to vary greatly from 
TABLE 7 Hourly catches of Aedes togoi from the evening of August 31 to the morning of September 1, 1971 at a hut* facing the seacoast, Mangchangpo, Che-ju Island

\begin{tabular}{|c|c|c|c|}
\hline Hours & Weather & Temp. C & No. females \\
\hline $19: 00-20: 00$ & cloudy & 25 & $2 * *$ \\
\hline $20: 00-21: 00$ & cloudy & 25 & 0 \\
\hline $21: 00-22: 00$ & cloudy & 25 & 3 \\
\hline $22: 00-23: 00$ & rainy & 24 & 3 \\
\hline $23: 00-24: 00$ & rainy & 24 & 9 \\
\hline $24: 00-1: 00$ & cloudy & 23 & 3 \\
\hline $1: 00-2: 00$ & cloudy & 23 & 4 \\
\hline $2: 00-3: 00$ & cloudy & 22 & 30 \\
\hline $3: 00-4: 00$ & cloudy & 23 & 30 \\
\hline $4: 00-5: 00$ & cloudy & 22 & 12 \\
\hline $5: 00-6: 00$ & cloudy & 23 & $4 * * *$ \\
\hline
\end{tabular}

* Four persons spent the night inside the hut.

** Females resting at the dark place of the hut.

$* * *$ No females were encountered after 5: 30 .

day to day, possibly due largely to the difference in meteorological conditions. Without the rainy weather before the midnight, the peak of biting activity would have been found at the time nearer to the midnight. At least, it can safely be said that $A e$. togoi in Che-ju Island is a night-time feeder, since Wada (1966) reported that $A$ e. togoi has a peak in biting activity around mid-night on Goto Ialsnds, Japan, which is situated near to Che-ju Island, and also in our present survey neither biting nor flying of $A$ e. togoi females was encountered at the day-time during the mosquito survey at dwelling houses and at their breeding places even when it was cloudy.

\section{Dispersion of Mosquitoes}

Patients of malayan filariasis in Wimi-1-Ri were apparently more frequently found in the coastal area than in the inland area. In connection with this distribution of patients, the mean number per house of the females of Ae. togoi, the main vector of malayan filariasis in Che-ju Island, was illustrated for each of 19 Bangs of Wimi1-Ri in Fig. 2. It is clearly shown from Fig. 2 that the density of the mosquito was higher in the coastal area than in the inland area, indicating the close relation between the distributions of filaria patients and vector mosquitoes. For comparison, the mean numbers of another dominant species, C. p. pallens, were given in Fig. 3. There was not shown any tendency for the females of $C$. p. pallens to concentrate toward the seacoast. 


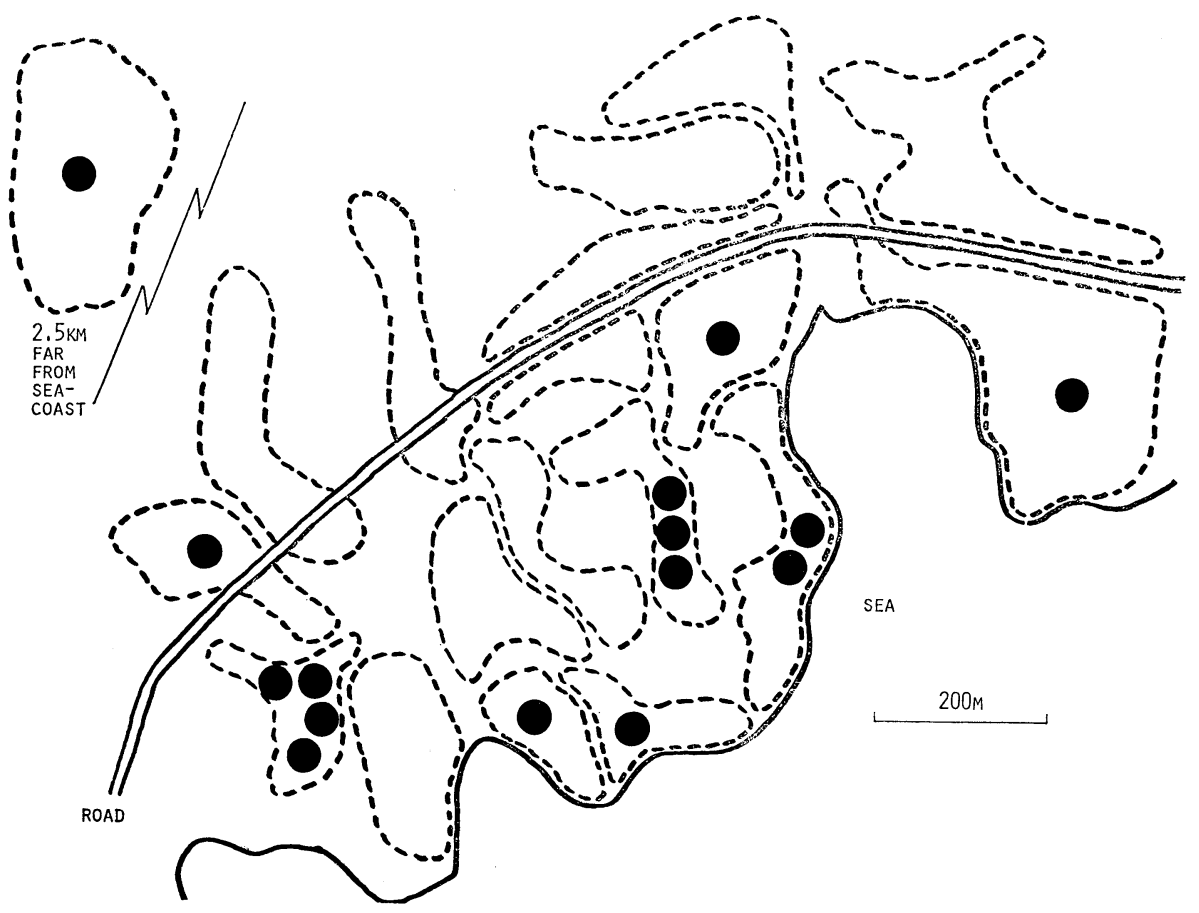

Fig. 2 Mean number per house of Aedes togoi females collected in each of 19 Bangs of Wimi-1-Ri, Che-ju Island, 1970. One circle represents one female, and the Bang without the circle designates that the mean number was less than O.S.

To examine the distribution tendency of mosquitoes, another attempt was made in 1972. In Wimi-1-Ri five sites were fixed for the mosquito catches by light traps, the site No. 1 being nearest to and No. 5 farthest from the seacoset, as shown in Fig. 4. Light traps were operated in 10 nights from late August to early September, and the numbers of female mosquitoes collected are presented in Table 8. It is again indicated that the density of $A e$. togoi was generally higher at the site nearer to the seacosat while the density of $C$. p. pallens, and of other mosquitoes too, had no tendency to differ with the distance from the seacost.

These distribution patterns of the two mosquito species can easily be understood by the facts that the larvae of $A e$. togoi were found almost exclusively in rock pools on the seacoast, as seen in Fig. 4, while the breeding places of $C . p$. pallens were artificial containers, road-side ditches and others which were common around dwelling houses.

The fact that the breeding place of Ae. togoi is limited nearly to the seacoast indicates the ability for the mosquito to fly a long distance, since the females must 


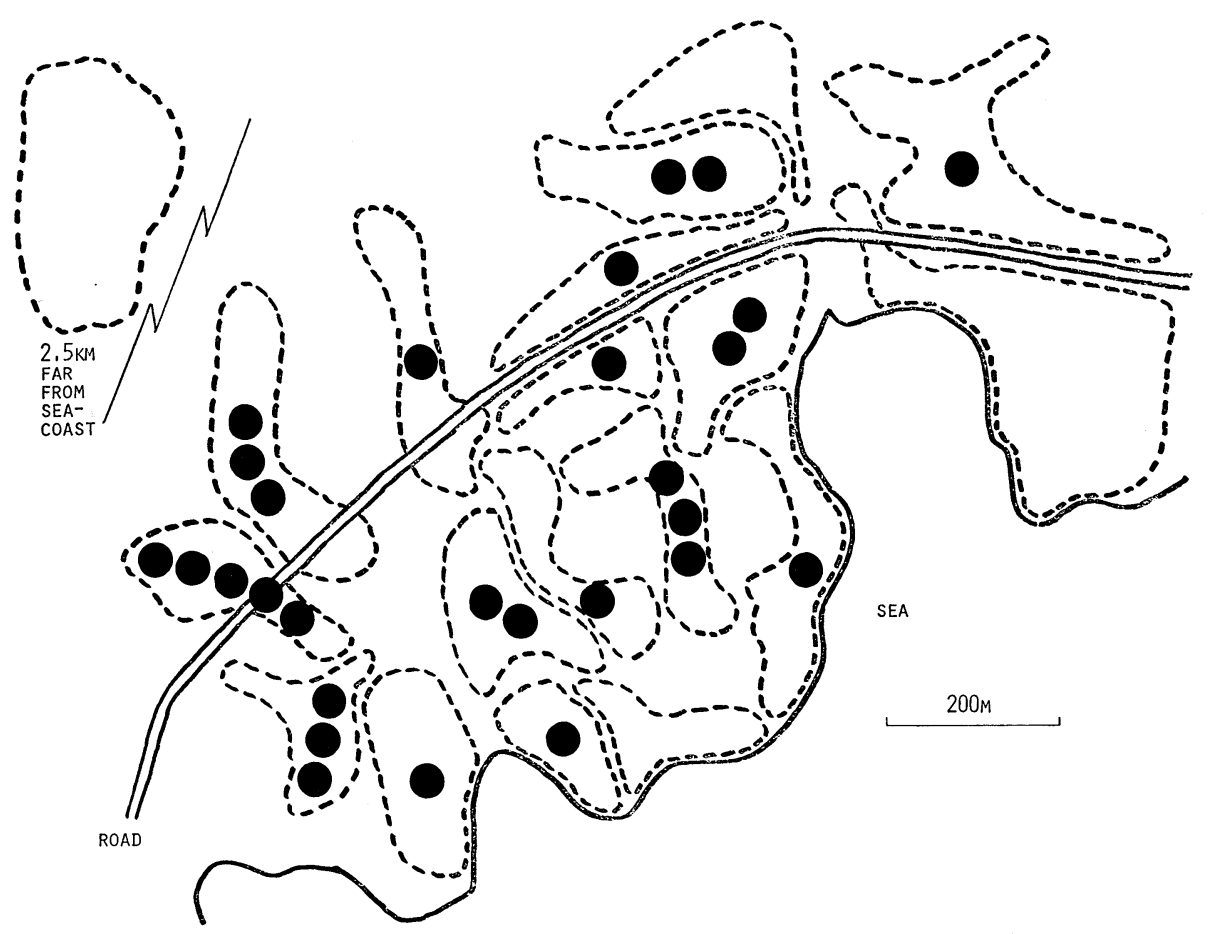

Fig. 3 Mean number per house of Culex pipiens pallens females collected in each of 19 Bangs of Wimi-1-Ri, Che-ju Island, 1970. One circle represents one female, and the Bang without the circle designates that the mean number was less than 0.5 .

fly to dwelling houses from the seacoast to feed on man and the engorged ones must return to the seacoast to lay their eggs even when they took the blood-meal far from the seacost. In fact, the dispersal experiment around a village in Uku Island, Nagasaki Prefecture, Japan indicated that Ae. togoi can fly several km (Wada et al., unpublished). It is interesting that in spite of their strong flight ability the density of the females is generally higher at houses in the coastal area than at those in the inland area. In other words, the females which have just oviposited are apt to feed on blood at houses near to the seacost. This is very important in that the risk of humans to be infected with malayan filariasis is always greater in the coastal area wherever the place with high endemicity is situated, so far as $A e$. togoi is the main vector. Another interesting point derived from the behavior of $A e$. togoi mentioned above is that the familial aggregation of filaria patients, as seen in the case of bancroftian filariasis transmitted by C. p. pallens with a short flight range (Omori, 1965), would not be expected. 


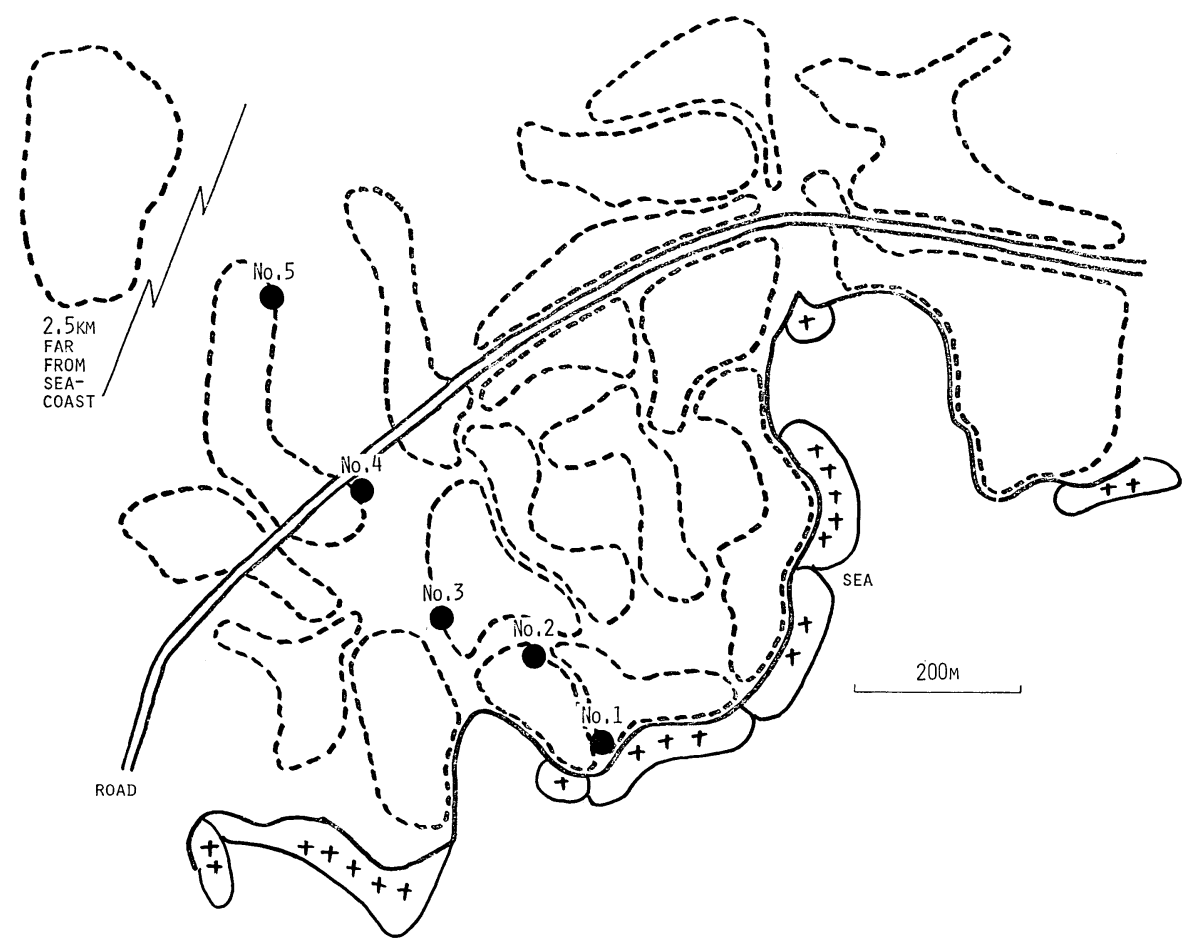

Fig. 4 A map of Wimi-1-Ri showing the sites of light trap collections in 1972 (No. 1-5) and the relative density of Aedes togoi larvae (plus signs).

TABLE 8 Numbers of female mosquitoes collected by light traps at the five sites in Wimi-1$\mathrm{Ri}$ in 10 nights from late August to early September, 1972

\begin{tabular}{|c|c|c|c|c|c|c|}
\hline Collection site No.* & 1 & 2 & 3 & 4 & 5 & Total \\
\hline An. sinensis & 2 & 4 & 2 & 4 & 6 & 18 \\
\hline Ar. subalbatus & 1 & & 4 & & & 5 \\
\hline Ae. togoi & 168 & 112 & 120 & 51 & 82 & 533 \\
\hline Ae. vexans nipponii & & 1 & & & 3 & 4 \\
\hline C.p.pallens & 11 & 8 & 39 & 13 & 7 & 78 \\
\hline
\end{tabular}

* See Fig. 4

\section{Acknowledgement}

We wish to express our cordial appreciation to Dr. B. S. Seo, Dr. H. J. Rim, Dr. J. H. Kim, and other staffs of the Department of Parasitology, Seoul National University who kindly cooperated with us. Our sincere thanks are also due to the Japanese members of the survey teams, particularly Dr. A. Sato of the Department 
of Medical Zoology, Kagoshima University School of Medicine, for their encouragement and help.

\section{REFERENCES}

1) Chun, S. R. (1968): A preliminary survey of mosquitoes of Che Ju Do related to filariasis on species, biology and infection status (In Korean with English summary), Korean J. Publ. Hlth., 5: $113-121$

2) Gun, D. C. (1960): A new carrier of human filariasis in China (In Russian with English summary), Med. Parazit. (Mosk.), 29: 98-101 (Rev. Appl. Ent. B, 50: 168, 1962)

3) $\mathrm{Hu}, \mathrm{S} . \mathrm{M} . \mathrm{K}$. (1940a): Studies on the susceptibility of Shanghai mosquitoes to experimental infection with Microfilaria malayi Brug. 1. Culex pipiens var. pallens Coquillett, Pekin Nat. Hist. Bull., 15: 87-91

4) $\mathrm{Hu}, \mathrm{S} . \mathrm{M} . \mathrm{K} .(1940 \mathrm{~b})$ : Studies on the susceptibility of Shanghai mosquitoes to experimental infection with Microfilaria malayi Brug. III. Anopheles hyrcanus var. sinensis Wiedemann, Pekin Nat. Hist. Bull., 15: 97-101

5) $\mathrm{Hu}, \mathrm{S}$. M. K. (1948): Notes on the experimental infection of Culex pipiens var. pallens Coq. with Microfilaria malayi Brug, Lingnan Sci. J., 22: 79-83

6) Kim, H. K. and Seo, B. S. (1968): Studies on filariasis in Korea on the morphology and development of larvae of Brugia malayi in Aedes togoi (In Korean with English summary), Korean J. Parasit., 6:1-11

7) Lee, W. Y. (1969): A study on Aedes togoi as vector of filariasis in Che Ju Island (In Korean with English summary), Korean J. Parasit., 7: 153-159

8) Omori, N. (1957): Experimental studies on the role of the house mosquito, Culex pipiens pallens in the transmission of bancroftian filariasis. 1. Development, distribution and longevity of filariae in mosquitoes kept at $27 \mathrm{C}$ and $25 \mathrm{C}$ (In Japanese with English summary), Nagasaki Med. J., 32: 1434-1445

9) Omori, N. (1965): On the familial infection of bancroftian filariasis due to the house mosquitoes, Endem. Dis. Bull. Nagasaki, 7:29-37

10) Sasa, M., Hayashi, S., Kano, R., Sato, K., Komine, I. and Ishii, S. (1952): Studies on filariasis due to Wuchereria malayi (Brug, 1927) discovered from Hachijo-Koshima Island, Japan, Jap. J. Exp. Med., 22: 357-390

11) Wada, Y. (1966): Epidemiology of bancroftian filariasis in Nagate and Abumize Villages, Nagasaki Prefecture, especially in relation to vector mosquitoes. 3. Ecology and natural infections of mosquitoes, Endem. Dis. Bull. Nagasaki, 8: 45-53 
韓国済州島のマレー系状虫に関する研究

2 マレー系状虫の伝搬蚊

和田義人 ${ }^{1} \cdot$ 片峰大助 $^{2} \cdot$ 吳 文儒 $^{3}$

済洲島において1970〜1972年の 8，9月に蚊の採集を行なって合計14種を得たが，その中で人家内で 住民から主として吸血をするのはアカイエカとトウゴウヤブカであった。また，マレ一糸状虫の感染幼 虫による自然感染はトウゴウヤブカにおいてのみ見られた。以上のことから，済洲島におけるマレ一系 状虫症の主伝搬蜘はトウゴウヤブカと考方られる。他地方でマレ一系状虫症の伝搬者として知られるシ ナハマダラカは，済洲島では幼虫の発生場所が極めて少なく，伝搬に重要な役割を果しているとは考兄 られない。マレー糸状虫の幼虫がトウゴウヤブカ体内で成熟するに要する日数は，患家で採集した雌成 虫を種々の期間飼育の後に解剖した成績から，夏では 6 ～9 日推定された。これはバンクロフト糸状 虫の場合と比べるとずっと短い。トウゴウヤブカの幼虫は主として海岸の岩の水たまりから発生し，部 落の中での発生は極めて少ない。本種の雌成虫は海岸近くの人家で多く, 内陸部に入るほど少なくなる 傾向が見られ，マレー系状虫症の患者の分布にも同椂の傾向が見られる。

1 長崎大学医学部 医動物学教室 2 長崎大学熱帯医学研究所 奇生虫学部門 3 済州大学農学部 獣医学教室 